\title{
Re-conception of Government's Role in Implementing Telecommunication in Digital Era
}

\author{
Abdul Karim ${ }^{1 *} \quad$ I Nyoman Nurjaya ${ }^{2} \quad$ Istislam $^{3} \quad$ Moh. Fadli $^{3}$ \\ 1.Doctorate Candidate of Law Faculty, Brawijaya University, MT Haryono No. 169, Malang, Indonesia, 65145 \\ 2.Professor of Anthropology of Law, Brawijaya University, MT Haryono No. 169, Malang, Indonesia, 65145 \\ 3.Postgraduate Program of Law Faculty, Brawijaya University, MT Haryono No. 169, Malang, Indonesia, 65145
}

\begin{abstract}
Telecommunication is governed in Law Number 36 of 1999 concerning Telecommunication specifically related to the authority to implement telecommunication, where it regulates that the private sectors are assigned as implementers while the government serves as a supervisor. These divided roles seem no longer relevant to the present condition, in which there are gaps in the distribution of telecommunication network. On the contrary, telecommunication is initially aimed to fairly and evenly distribute welfare to the people. Liberalization of telecommunication that has taken place since 2000 is a policy that embarks from politics because Indonesia is committed to World Trade Organization (WTO) Agreement to liberalize telecommunication. Moreover, Indonesia faces suppression from International Monetary Fund (IMF) regarding the funding given by the IMF to recover the Indonesian economy following economic crisis back in 1998. This condition triggered the country to liberalize telecommunication while this sector is considered as of important production sectors controlled by the state and for the welfare of the people. This control is supposed to exist through the direct role of the government in the implementation. The challenge Indonesia is facing these days regarding strategic telecommunication is the development of digital economy and fulfillment of right to access to information owned by the citizens as mandated by the Constitution.
\end{abstract}

Keywords: government, implementation, telecommunication.

DOI: $10.7176 / \mathrm{JLPG} / 92-13$

Publication date: December $31^{\text {st }} 2019$

\section{Introduction}

The government's role in implementation of telecommunication in Indonesia is only restricted to as a supervisor, with the extent of authority ranging from setting policy, regulation, supervision, and control. (Law Number 36/1999 concerning Telecommunication, "Article 4 Paragraph 2). The implementation of telecommunication, however, is left in the hand of private sectors comprising State-owned enterprises (hereinafter BUMN), Localowned Enterprises, private companies, and cooperatives. (Law Number 36/1999 concerning Telecommunication,", Article 8 Paragraph 1).

The policy to divide roles has placed Indonesia in a liberal position in telecommunication implementation. Private sectors play a central role in telecommunication industry, while the Government is responsible for providing fundamental policy, regulation, agreement, and supervision over the implementation.

Liberalization politics in telecommunication started when Law Number 36 of 1999 concerning Telecommunication was passed and has been in place since 1 September 2000. Earlier, Indonesian Government referred to duopoly policy through two State-owned Enterprises such as PT Telkom and PT Indosat, both of which served as implementers of telecommunication (Law Number 3/1989 concerning Telecommunication, Article 12). Indonesian Both BUMN as implementers hold the control over the implementation of telecommunication service. Pure monopoly in telecommunication sector was apparent before 1989 through Telecommunication Company. (Government Regulation Number 36 of 1974 concerning Telecommunication Public Company. Article 3).

The change in policy of telecommunication sector took place following the ratification of World Trade Organization (WTO) agreement, backed up with the Law Number 7 of 1999. The organization initiated and established by developed countries is binding to all its members. One of the responsibilities of the member states of the WTO is to liberalize telecommunication implementation.(Budhijanto 2013, p.15) This is how the path of liberalization started to form, as regulated in Law Number 36 of 1999 concerning Telecommunication. Legislation process of the Law took place briefly. Only within about three months after session I in House of Representatives on 12 July 1999, Law concerning Telecommunication was signed by President BJ Habibie on 8 September 1999. (Panjaitan 2000, p.3).

This brief legislation process was formed in the mid of the crisis of Indonesian economy in the last decade of the 90s. The crisis attracted the IMF to help recover the Indonesian economy. The assistance given by the IMF came with several requirements related to liberalization of telecommunication sector. On 15 January 1998 President Soeharto signed Letter of Intent (LoI) before Managing Director of IMF Michel Camdessus. This was revealed in the report of the Finance Minister of Indonesia to IMF in January 2000. (Indonesia Government 
Report, point 71). All the facts mentioned above bring to a conclusion that transformation from duopoly to a full competition was mostly triggered by political factors.

Following the policy concerning telecommunication liberalization, Indonesia has witnessed that the telecommunication industry has grown well; this is obvious in the significant rise of subscribers in the first ten years in the industry. Tele density of fixed phone rose from 3.60 per 100 persons in 2002 to 5.9 in 2010 . (Mastel $2005, \mathrm{p} 8$ ). Indonesia followed the vast development of telecommunication well. However, since 2010, the growth has slowed down. From 2010 - 2016, the average accounted for $2.78 \%$, and the popularity of mobile phone saw an upsurge; from 2006 to 2015, the average increase in mobile phone users was $26 \%$ yearly. (Ministry of Communication and Informatics 2017). The sluggish growth in telecommunication industry in Indonesia can be seen, in large-scale perspective, from the measurement result by International Telecommunication Union. For fixed phone, the tele density per 100 persons in Indonesia back in 2017 accounted for 4.2. However, back in 2010, it was at 5.9. Indonesia is placed under the average of Asia Pacific and the world, accounting for 10 and 13 respectively. Thus, Indonesia is left behind for fixed phone, even behind Vietnam reaching 5.94\%. The use of Internet in Indonesia in 2018 represented the average of 39.9\%, while it was up to 51\% worldwide. In general, ICT Development Index in Indonesia ranked 111 out of 176 countries. (ITU 2017).

In a large-scale perspective, the backwardness of Indonesia in terms of the development of ICT is more apparent due to the gaps of infrastructure distribution either in quality or in quantity. Survey conducted by the Association of Indonesian Internet Service Providers (APJII) in 2016 showed extreme fluctuation. The penetration into Java accounted for the highest (65\%), while outside Java represented the maximum of $15.7 \%$ (Sumatera). The smallest figure was seen in eastern part of Indonesia (2.5\%). (Ministry of Communication and Informatics, (2017), Yearly Report 2016, p. 62).

Underdeveloped, remote, and outermost regions have faced discrimination in opportunity to access information. However, the citizens have their rights to access information since theirs are guaranteed in Article 28F of the 1945 Indonesian Constitution. In terms of the network quality, out of 514 cities, only 297 (57.78\%) are connected to Mobile broadband network. (Ministry of Communication and Informatics, Yearly Report 2017).

This situation happens for a reason. Since the Government was not active in telecommunication implementation, private sectors were given authority in the industry. The principles held by private companies in running their business program tend to be profit-oriented, leading to a situation where telecommunication sector is more common among urban people who can pay more profit. Moreover, open competition in telecommunication sector sparks reliance on, gap, and unfairness in telecommunication, in addition to contributing profit to promising business fields.

When this is the case, the Government has no more room to act. As a supervisor, the Government is not quite influential in determining the distribution of telecommunication infrastructure. The Government's interference through BUMN, for example, is hampered by existing regulation. PT. Telkom, the only company where the majority of Indonesia's share is invested, has transformed to an independent Limited Liability Company, where interference from the Government is not possible.

Indonesian Government also has great obsession for the telecommunication in globalization in the $21^{\text {st }}$ century; it wishes to be a digital economic actor. This new economic model is expected by the state, consisting of 266 million people. The Government's devotion is reflected in long-term development plan for telecommunication sector as enacted in Law Number 17 of 2007. "Globalisation, technological development, and increasing needs of the people for access to information demands perfection in terms of implementation of post and telematics development. As a consequence, integration of education, information technology, and other strategic sectors is required. Although post and telematics development these days have improved, information is still seen luxurious and can only be accessed and owned by a small number of people. Therefore, the main challenge faced in this sector is related to maximising distribution and utilisation of information and teledensity in post and telematics services for people as users. Another challenge is convergence of information and communication technology that breaks the barrier obstructing telecommunication, broadcasting and information technology, education, and moral ethics" (National Long Term Development Plan (RJPN) 2007, point II.2.D.3). The long-term development is then elaborated in several programs comprising Indonesian Broadband Plan and Road Map E-commerce Indonesia.

The broadband plan with the priority placed for development is aimed to support five sectors: eGovernment, e-Health, e-Education, e-Logistics, and e-Procurement. (Presidential Regulation of Indonesia 2014, Number 96, Article 7 Paragraph (1). This priority is inextricable from the strategy aimed to stimulate the economic growth and national competitiveness and to improve the quality of life of the Indonesian societies.

The Government also has a big dream to transform Indonesia to a state with the biggest e-commerce industrial ecosystem in Southeast Asia in the next five years (2022). The president of the state has released an instruction to make Indonesia go digital, with projected e-commerce transaction values accounting for US\$ 130 billions in 2020. (Ministry of Communication and Informatics, (2018), yearly report 2017, p. 27). 
More importantly, the second amendment to the 1945 Indonesian Constitution has transformed the rights to access information to constitutional rights of the citizens. In other words, availability of access to information should be the priority to fulfill the responsibility of the Government as mandated by the Constitution. "Every person has a right to communicate and to obtain information to develop their personality and social network, to seek, to obtain, to have, to save, to process, and to deliver information through all devices available".(UUDRNI 1945, Article 28F). The members of People's Consultative Assembly that amended the 1945 Constitution believe that the openness of information is a strategy that can create good and transparent governance that will lead further to improving control by democratic society towards the Government.

This hope is not easily realized due to Indonesia's geographical condition consisting of the fourth biggest population worldwide. One of the effective ways to provide access to information for the state like Indonesia is to utilize the advanced communication technology, and this is seen as the importance of evenly distributed telecommunication network.

This condition has stimulated the author to analyze the concept of Government's role in implementation of telecommunication that is aimed to provide a law that is adaptable to the need of and the rapid change in the world of information and communication technology.

\section{Results and Discussion}

\subsection{Grounds for Liberation}

The state's policy in telecommunication is inseparable from the perspective towards telecommunication per se. Following the independence of Indonesia up to 1965, telecommunication has been utilized as infrastructure and a tool to maintain the independence and to continue the unfinished revolution (Government Regulation in Lieu of Law Number 6/1963). Since the New Order was in place to 1989, telecommunication has been utilized as a tool that assists development. The state absolutely monopolized the telecommunication. From 1989 to 1999 , the government initiated to give space to private sectors to take part in the telecommunication industry, but the control still lay in the hand of the Government (Law Number 3/1989). Dramatic change was apparent in 1999, and to date, telecommunication has been seen as a pure economic commodity. Private sectors are deemed capable of implementing telecommunication since privatization takes place in the right time, and the government, thus, can entirely leave its job to private sectors.

However, seen from the international geo-political map, massive change in telecommunication implementation in Indonesia is actually connected to the participation of Indonesia in WTO. Danrivanto (2013), Indonesia also signed multilateral agreement concerning Basic Telecommunication in February 1997 under the supervision of WTO mainly involving the commitment of the 69 states worldwide including Indonesia to bring pro-competitive regulation of telecommunication to the fore. (Budhijanto 2013). Indonesia abides by the international agreement, and this positive condition allows the liberalization in telecommunication sector.

In addition to the commitment with WTO, Indonesia is also bound to the Letter of Intent (LoI), signed by President Soeharto early in 1998, in which a point mentions de-regulation in several sectors in Indonesia including telecommunication sector. In other words, liberalization in telecommunication sector is not on the basis of the real needs of Indonesia, but it is merely because of the consideration that is more internationally political. Thus, the shift of telecommunication from duopoly to a full competition is more likely to be based on political consideration because of certain situations faced by Indonesia in the past.

As a state suffering from multi-dimension crisis and proposing aid from IMF for economic recovery, Indonesia has faced serious dilemma. This situation was cunningly seen as a chance for foreign power to influence the economic policy of Indonesia. Legislative product that was passed following the 1998 reform tended to be capitalistic. Law concerning Water Resources and law concerning Electric Power are two sectors once became the victims of capitalism. Fortunately, Indonesia has its Constitutional Court as the guard of constitution. Constitutional Court, however, revoked the Law Number 20 of 2002 concerning Electric Power and Law Number 7 of 2004 concerning Water Resources contravening the Constitution.

\subsection{Economic Principle based on Article 33 of the 1945 Indonesian Constitution}

The most essential and substantial debate arising from the law reviewed in Constitutional Court is related to the concept of control held by the state over natural resources and important production sectors. The Constitutional Court Decision Number 001-022/PUU-I/2003 led to scrapping Law Number 20 of 2002 concerning Electric Power because the Law gave a chance to private sectors to control electrical resources while they should be of important production sectors for the state and is for the livelihood of the people, but Article 33 of the 1945 Indonesian Constitution suggests that it should be under the control of the state.

The consideration by the Judge of Constitutional Court in formulating the concept of control by the state is that the Government should have five functions of control in terms of management of important production sectors, including Belied (policy), Regellend (regulation), Bestuur (administration), Beheers (management), and toezichthoudend (supervision). All these total controls are to assure that the important production sectors for the 
state and for the livelihood of the people should be used for the welfare of the entire people. (Constitutional Court Decision 2015, Number 111/PUU-XIII/2015, p. 102-104).

In telecommunication sector, since it is liberalized, private sectors can entirely hold control over telecommunication. Out of 7 telecommunication operators operating in Indonesia, five are owned by private companies, either foreign or local ones, while two of them hold government's share accounting for 14,29\% in PT Indosat Ooredoo and 52.09\% in PT. Telkom. Although Indonesia has major share in PT Telkom, its government still has no strong influence in determining to which direction the development of the company is brought since PT Telkom is an independent Limited Liability Company whose share $(47.91 \%)$ is owned by public. (PT. Telekomunikasi Indonesia, Tbk, (2019), Yearly Report 2018, p.78)

With the substantive material from Constitutional Court Decision regarding perspective towards a policy in telecommunication sector, a new question of whether telecommunication liberalization contravenes Article 33 of the 1945 Indonesian Constitution is raised.

\subsection{Revival of the State}

A discussion on the role of the state in an economic system receives its answer from welfare state. "The basic notion of welfare state dates back to the $18^{\text {th }}$ century when Jeremy Bentham (1748-1832) promoted the notion implying that the government had responsibility to guarantee the greatest happiness or welfare for the greatest number of their citizens". (Keyness and Smith 2006). But to Indonesia, the state's role in economy is final and no longer a mere theory but it is a norm. Founding fathers of Indonesia added Article 33 to the 1945 Indonesian Constitution. Explored further, Article 33 actually stems from the second paragraph of the Preamble of the Constitution that comes from the basis of ideal fundamental of the fifth principle of Pancasila (Five Principles): Social Justice for all people of Indonesia, which is expected to be internalized into the economic system, or commonly recognized as "joint and kinship-based cooperation". This expectation is there for a reason. The founding fathers agree to come to a conclusion that capitalist system implemented during Dutch colonialism sparked hardship and unfair control over assets among certain members of public. Therefore, this country was built on the concept of gotong royong (mutual cooperation) and togetherness.

The national economic system as enacted in the constitution implies that the state holds control over and intervenes the management of economic sectors. The sectors directly managed by the state, as in Article 33 Paragraph (2) and (3), involve (a) land and waters and natural resources contained therein (b) important production sectors for the state and is used for the greatest benefit of the people. The two categories are absolutely under the control of the state and are used for the greatest benefit of the people. Another sector can be handled by private sectors proportional to their capacity.

The understanding of the concept of control by the state has dynamically developed. Manan (1995, p.12) argues that "control by the state involves (1) control regarding ownership by the state, meaning that the state, through government, is the only element that holds an authority to decide the rights to the authority above it, including control over land, waters, and resources therein, (2) regulation and supervision over utilization, (3) investing capital to state-owned enterprises for particular businesses."

"The concept of "control by the state", refers to ownership in general scope, ownership within the scope of public law. Land and waters and all natural resources contained in earth and waters cannot be merely understood as control through regulations." (As-shiddiqie 2016),

Control over telecommunication sector by the state is facing uncertainty. Ambivalence of the government is apparent as inconsistent law because perspective toward telecommunication as of important production sectors for the state basically never changes. It is proven from the explanation delivered in the Law concerning Telecommunication: "Telecommunication is of important production sectors at national level, and the control is held by the state. The implementation is aimed for the greatest benefit and welfare of the people". (Law of Telecommunication 1999, Number 36, Part Explanation of Article 4 Paragraph 1). On the other hand, Law concerning BUMN states criteria of production sectors that are privatized involve those related to technology. This contradiction escalates complexity when it is linked to the commitment of Indonesia as a member state in WTO.

The position of legal uncertainty in telecommunication sector is the perfect momentum to bring back the state in telecommunication industry in the nation. There are several fundamental grounds as consideration of ratio legis that will be further explained.

State's interference in a competitive industry that has been around for 20 years might be getting contradictive and counter-productive. Perhaps there are several parties seeing this condition as backwardness and as a policy that contravenes mainstream, but from theoretical perspective or basic norm of national economy in the constitution, the revival of the state into the telecommunication sector redirects the dream of the state back to its track. To assure this perspective, we can refer to a notion by Francis Fukuyama, a world expert, about fundamental changes.

Fukuyama (1992) argues that global capitalism will win the fight and marks its victory in the history. 
However, in the following 12 years (2004), he re-consider his notion after seeing facts that war, poverty, global terrorism that have taken place in this world due to the disappearance of state dimension make the state fragile. This lost dimension means the state fails to run its primary function among societies. In such a situation, Fukuyama suggested that there ought to be an agenda aimed to strengthen the state's function and role. Fukuyama suggests that people's welfare still requires the interference of the state (Fukuyama, 2004:xi).

In a smaller scale, this notion seemingly has come true in the stagnation of telecommunication in Indonesia. Liberalization within the last 20 years that increasingly involves the role of the private sectors and simultaneously shrinks the role capacity of the state in the industry has left this state far behind the development of ICT sector in the world and Indonesia is left with its only limited role.

\subsection{Saving obsession of digital economy}

Digital economy is an alternative economic system that will develop in the future and Indonesian Government is convinced that digital economy becomes one of the pillars of national economy. (Presidential Regulation (2017) Number 76, Part Consideration). To give way to the needed projects, telecommunication infrastructure, which obviously cannot rely on the role of private sectors, is required. Therefore, the government needs to intervene in the development of telecommunication.

Looking at this issue, the author is assured that the comeback of the government to the management of telecommunication should not be seen as backwardness or counter-productive action, but the comeback is aimed to save telecommunication industry as the most reliable backup in digital economy.

\subsection{Rights to access information}

Since 2000, the citizens of Indonesia have had constitutional right to access information. The provision relating to this is detailed in Law concerning Openness in Public Information. The compulsory task of the State, in this case the Government, in terms of fulfilling the rights of the people of the state, is closely related to the sufficient and quality availability of telecommunication network. Secondly, it has something to do with accessibility, where telecommunication must be easily reached, and thirdly, affordability. The cost of broadband telecommunication service at present time is 5\% above of Regional Minimum Wage, (Ministry of Communication and Informatics 2017, Performance Report, p. 17).

\subsection{Government's Empirical Experience}

The is aware of rule of law in telecommunication industry that does not allow any government's intervention. However, the need for infrastructure of telecommunication is at critical level. Private sectors as implementers cannot be relied upon to take over the responsibility. As a consequence, the government came up with the idea of Palapa Ring project as a breakthrough. Palapa Ring is the project in telecommunication sector structured as partnership between Government and Business Entity (KPBU)/Public Private Partnership (PPP), which is aimed to reach remote regions that are not financially feasible. This project started in 2016 and was completed in 2019, including 57 regencies/cities with network length reaching $2,275 \mathrm{~km}$ to the west, $2,995 \mathrm{~km}$ in the centre, and $6,878 \mathrm{~km}$ to the east.

This project shows that the Government eventually has to be responsible for the availability of the important production sectors for the state that should cover the needs of the people despite the national policy delegating telecommunication implementation to private sectors. Privatization is aimed to share the burden of cost with the private companies. The Government has given an exclusive concession to private companies to exploit telecommunication as economic commodity.

However, the correction on the policy that has been taken over is no longer taboo. The policy in the past is no longer seen as an error since it was selected as the right solution. Dynamic policy will allow a transformation since telecommunication industry has radically changed. Palapa Ring project can empirically settle issues in the short term. However, principally, the state has intervened in privatization in telecommunication through the mechanism that is irrelevant to the Law concerning Telecommunication.

The Government is forced to use discretionary power, but as a state of law, each policy taken and provided in the hierarchy of legislation must not raise uncertainty, especially when it comes to telecommunication that involves public interest. Therefore, the degree of the hierarchy of legislation needs legitimation at the level of law.

\subsection{Reformulating Concept of Government's Role}

The facts mentioned above head to a point where the concept of Government's role in implementing telecommunication in the present time holds a strong fundamental for a review for a new concept (re-conception) that should be more accommodative and legitimated:

Philosophical momentum. The Government's intervention in telecommunication implementation is consistent to what is mandated in Article 33 of the 1945 Indonesian Constitution since telecommunication is of 
important production sectors for the state and it is used for the greatest benefit of the people, in addition to its another function as infrastructure to fulfill people's constitutional right to access information.

Political Momentum. The policy of privatization in telecommunication sector is part of national strategy where there is political negotiation therein. Therefore, the strategy is dynamic and flexible, where changes are possible from time to time. As a matter of fact, the government has made discretion of telecommunication network development in order to meet the needs that keep growing.

Juridical Momentum. This momentum is defined as to put the norm back on its track according to the degree or hierarchy of legislation, where lower legal norm must abide by higher norm above it.

Sociological Momentum. This momentum is aimed to fulfill the needs of the people to participate in digital economy and other aspects that majorly utilize information and communication technology as support.

\subsection{Proper Arena}

In which aspect the nation has to intervene? Is it with the privatization or centralization in telecommunication sector? There is of course a complex dilemma among the globalization, democratization, and privatization. Confrontation from parties that have benefitted from existing local or foreign policy cannot just be taken for granted. Another essential factor that also has to be taken into account is the implication of the participation of Indonesia in WTO, where there should be more cooperative solution. The author offers a notion (re-conception) in terms of the position of the state's/Government's role in implementing telecommunication.

Firstly, it is essential to understand that telecommunication sector is closely related to ever-changing technology, while Indonesia still has no capacity to lead the change in technology. Therefore, Indonesia is open to choices of arena that it is capable of.

Secondly, with the convergence of communication and information technology, the structure of industry has changed. Business Competition Supervisory Agency (KPPU) analyses that the change in the structure of telecommunication industry is in vertical and horizontal pattern. (KPPU 2012, p. 16).

From this change, it is apparent that access layer and transport/backbone layer are included in physical layer with which Indonesia is capable of dealing, and the change of the layers is not as rapid as the two layers above them. For application and content, privatization policy still applies. Indonesia has proven that it could run Palapa Ring project and it is capable of operating communication satellite.

This measure answers several issues regarding availability, accessibility, and affordability in telecommunication in Indonesia. The presence of the state/Government in network implementation will at least break the impasse in telecommunication sector. Secondly, liberalization in telecommunication sector will keep running since the state has taken over the entire implementation. Thirdly, partnership between the Government and private sectors will serve as win-win solution model in order to improve productivity and national efficiency.

Collaboration model in telecommunication sector was once implemented in Indonesia for 10 years (19891999) in duopoly era. During this era, the Government divided the structure of communication industry into two: basic telecommunication and non-basic telecommunication (value added service). For the latter, private companies could perform the implementation on their own, requiring no partnership with another implementing institution, while in the former, whoever has the capacity to implement telecommunication is allowed to take part in but under the partnership with another implementing institution. (Law 1989, Number 3, Article 12 Paragraph (2)

\subsection{Institutions}

Another technical detail regarding the re-conception involves re-regulating the aspect concerning institution. With the presence of the Government in the arena of competition, there is a potential where unfairness may exist among implementers. When this is the case, an independent body as an umpire is required. In the US, a body called Federal Communicating Commission (FCC) is responsible to the Congress. This institution is an independent super body serving as a supervisory agency in the process of competition.

Indonesia has a body functioning to supervise called Indonesian Telecommunication Regulation Agency, but this agency is not seen as an independent institution since it was established by minister and is responsible to minister, and it is ex-officio. To maintain fair competition, an independent body having direct responsibility to the president is required.

The institution at operational level established by the Government as Telecommunication Implementer with the primary mission to provide proportional national backbone network is in the form of Limited Company whose share is entirely owned by Indonesia. The funding source comes from the separated state's asset.

\section{Conclusion}

Based on the above discussion, conclusion can be drawn as follows:

- Shared role between the Government and private sectors in implementing telecommunication hampers the goal of telecommunication since several regions are not within the reach of telecommunication 
network.

- Indonesian Government sets a big plan for the future to develop digital-based economic system, but unfortunately it is not supported by policy concerning infrastructure provision that is relevant to the norm in telecommunication implementation.

- Indonesia needs re-conception of Government's role in implementing telecommunication in order to better the old concept as a way to anticipate the needs in telecommunication industry in the future.

\section{Recommendation}

Based on the analysis and conclusion above, the author proposes the following recommendations for Indonesian Government:

- The Government should be given a role in the implementation of telecommunication.

- State-owned Enterprises (BUMN) as limited companies or as public companies should be established with the primary mission to evenly provide national backbone networks

- Independent Institution holding direct responsibility to the President should be established in order to guarantee the objectiveness of the policy, regulation, control, and supervision on telecommunication implementation.

- The Government should revise legislation related to the above recommendations, namely Law Number 36 of 1999 concerning Telecommunication especially articles concerning distribution of authorities to implement telecommunication, telecommunication implementation, and an agency/institution regulating telecommunication.

\section{Reference}

Asshiddiqie, Jimly, (2016), "Konstitusi Ekonomi”, Kompas Media Nusantara, Cetakan kedua, Jakarta.

Budhijanto, Danrivantio, (2013), "Hukum Telekomunikasi, Penyiaran \& Teknologi Informasi - Regulasi dan Konvergensi”, Refika Aditama, Cetakan Kedua, Bandung.

Fukuyama, Francis, (2004), "State-Building - Governance and World Order in The 21th Century", Cornel University Press, Ithaca, New York.

Panjaitan, Hinca, (2000), "Undang Undang Telekomunikasi Partisipasi Publik dan Pengaturan Setengah Hati”, Internews Indonesia. Jakarta

Manan, Bagir, (1995), "Pertumbuhan dan Perkembangan Konstitusi suatu Negara", Mandar Maju, Bandung.

Undang Undang Dasar Negara Republik Indonesia Tahun 1945 (Lembaran Negara Nomor 11 Tahun 2006, (Lembaran Negara Nomor 12 Tahun 2006, Lembaran Negara Nomor 13 Tahun 2006, Lembaran Negara Nomor 14 Tahun 2006).

Undang-Undang Republik Indonesia Nomor 3 Tahun 1989 tentang Telekomunikasi (Lembaran Negara Republik Indonesia Tahun 1989 Nomor 11 Tambahan Lembaran Negara Republik Indonesia Tahun Nomor 3391)

Undang Undang Nomor 36 Tahun 1999 tentang Telekomunikasi (Lembaran Negara Tahun 1999 Nomor 154, Tambahan Lembaran Negara Nomor 3881).

Undang Undang Nomor 19 Tahun 2003 tentang Badan Usaha Milik Negara (Lembaran Negara Tahun 2003 Nomor 70 Tambahan Lembaran Negara Nomor ).

Undang-Undang Republik Indonesia Nomor 17 Tahun 2007 tentang Rencana Pembangunan Jangka Panjang Nasional Tahun 2005 - 2025 (Lembaran Negara Republik Indonesia Tahun 2007 Nomor 33 Tambahan Lembaran Negara Republik Indonesia Nomor 4700)

Putusan Mahkamah Konstitusi Nomor 111/PUU-XIII/2015 tentang Pengujian Undang Undang Nomor 302009 tentang Ketenagalistrikan.

Peraturan Pemerintah Nomor 36 Tahun 1974 tentang Perusahaan Umum Telekomunikasi (Lembaran Negara Tahun 1974 Nomor 50)

Peraturan Presiden Republik Indonesia Nomor 96 Tahun 2014 tentang Rencana Pitalebar Indonesia 2014 - 2019 (Lembaran Negara Republik Indonesia Tahun 2014 Nomor 220).

Peraturan Presiden Nomor 76 Tahun 2017 tentang Peta Jalan Sistem Perdagangan Nasional Berbasis Elektronik.

Kementerian Komunikasi dan Informatika, (2018), Laporan Kinerja Tahun 2017.

Komisi Pengawasan Persaingan Usaha RI, (2010), Positioning Paper Terkait RUU Konvergensi Telematika.

Kementerian Komunikasi dan Informatika, (2017), Laporan Tahunan 2016.

Kementerian Komunikasi dan Informasi, (2017) Laporan Tahunan Information Communication Technology.

PT. Telekomunikasi Indonesia, Tbk, (2018), Laporan Tahunan 2017

PT. Telekomunikasi Indonesia, Tbk, (2019), Laporan Tahunan 2018.

Perhimpunan Masyarakat Telematika Indonesia (Mastel), (2005), Cetak Biru Telekomunikasi.

International Telecommunication Union, https://www.itu.int/net4/ITU-D/idi/2017/ accessed on 30 May 2018 6:51PM 